\title{
Exotoxin profiles of clinical isolates of Aeromonas hydrophila
}

\author{
JAMUNA VADIVELU, SAVITHIRI D. PUTHUCHEARY and PARASAKTHI NAVARATNAM \\ Department of Medical Microbiology, University Hospital, Faculty of Medicine, University of Malaya, 59100 Kuala \\ Lumpur, Malaysia
}

\begin{abstract}
Summary. Eighty-six clinical isolates of Aeromonas hydrophila were studied for their ability to produce four exotoxins: a haemolysin active against rabbit erythrocytes, cytotoxin and enterotoxin detectable with Vero cell cultures, and the cholera toxin-like factor detected by an enzyme-linked immunosorbent assay. At least one exotoxin was produced by $80 \%$ of enteric and $96 \%$ of non-enteric isolates. The exotoxin profiles of non-enteric isolates were more restricted than those of enteric isolates, with haemolysin and cytotoxin producers preponderant. Although haemolysin and cytotoxin were produced by isolates from all sources, the enterotoxin and cholera toxin-like factor were more common amongst enteric isolates. The production of haemolysin and cytotoxin were closely related but the association between the enterotoxin and the cholera toxin-like factor was not significant.
\end{abstract}

\section{Introduction}

During the last two decades it has been recognised that Aeromonas spp. are significant pathogens in man. A. hydrophila, in particular, causes wound infections and septicaemia in immunocompromised patients. ${ }^{1,2}$ Recent studies have implicated Aeromonas spp. as an important enteric pathogen in man, both in children ${ }^{3,4}$ and adults. ${ }^{5,6}$ This wide range of effects suggests that complex pathogenic mechanisms may be involved, in which strains of $\boldsymbol{A}$. hydrophila possess several virulence factors in different combinations.

Strains of $A$. hydrophila and $A$. sobria produce potential virulence factors such as cytolysin, ${ }^{7}$ haemolysin (aerolysin), ${ }^{8,9}$ cytotoxic enterotoxin, ${ }^{5,10}$ and a cholera toxin-like factor $(\mathrm{CTF})^{11}$ which have been recognised as virulence factors in other enteropathogenic bacteria. Although these properties resemble those of enteropathogenic Escherichia coli and Vibrio cholerae, the role of these exotoxins in the pathogenesis of aeromonas infections remains unclear.

In this study the exotoxin profiles of $A$. hydrophila isolates from various clinical specimens were examined to elucidate the possible role of these toxins in the pathogenesis of aeromonas infections in man.

\section{Materials and methods}

\section{Bacterial strains}

Eighty-six clinical isolates of $\boldsymbol{A}$. hydrophila from patients at the University Hospital, University of Malaya, Kuala Lumpur, Malaysia were examined.
They were from a variety of specimens including faeces from patients with diarrhoea, urine, pus, peritoneal dialysis fluid, blood, bile, throat swabs and tracheal secretions. The bacteria were isolated on oxblood agar (Oxoid), deoxycholate citrate agar (BBL) and biotyped with the API $20 \mathrm{E}$ system. ${ }^{10}$ All strains were stored at $4^{\circ} \mathrm{C}$ on Tryptone Soy Agar (Oxoid) slopes during the course of the study. E. coli WF5 (University of Surrey) of environmental origin was used as a heat-labile enterotoxin(LT)-negative control.

\section{Preparation of culture filtrates}

Cell-free culture supernates were prepared by the method of Cumberbatch et al. ${ }^{12}$ Bacterial strains were inoculated into Brain Heart Infusion Broth (BHI; Oxoid) and the cultures were incubated at $37^{\circ} \mathrm{C}$ with agitation at $100 \mathrm{rpm}$ for $18-24 \mathrm{~h}$. The broth cultures were then centrifuged at $12000 \mathrm{~g}$ for $20 \mathrm{~min}$, and the supernates were sterilised by filtration through 0.45 $\mu \mathrm{m}$ filter acrodiscs (Gelman). The cell-free culture supernates were stored at $4^{\circ} \mathrm{C}$ and tested in assays within 2 weeks of preparation.

\section{Haemolysin assay}

Haemolytic activity was assayed as described by James et al. ${ }^{13}$ Cell-free culture supernate $(100 \mu \mathrm{l})$ was added to each well of a 96-well microtitration plate and incubated with an equal volume of rabbit erythrocyte $1 \%$ suspension in phosphate-buffered

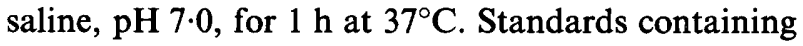
$0-100 \%$ lysed rabbit erythrocytes were prepared and all samples showing haemolytic activity $\geqslant 50 \%$ haemolysed erythrocytes were described as positive for the presence of haemolysin. 


\section{Cytotoxin and enterotoxin assays}

Vero cells at a concentration of $10^{4}$ cells/well in microtitration plates were used for the detection of both the cytotoxin and enterotoxin. ${ }^{14-16}$

For the detection of cytotoxin activity, the cells were exposed for $18 \mathrm{~h}$ at $37^{\circ} \mathrm{C}$ to $50 \mu \mathrm{l}$ of culture supernate. A positive response was recorded when $\geqslant$ $50 \%$ of the cells were lysed. Enterotoxin activity was assayed by exposing the cells for $18 \mathrm{~h}$ at $37^{\circ} \mathrm{C}$ to $50 \mu \mathrm{l}$ of culture supernate that had been heated at $56^{\circ} \mathrm{C}$ for 10 min to denature any cytotoxin present. ${ }^{17} \mathrm{~A}$ positive response was recorded when $\geqslant 50 \%$ of cells showed morphological changes attributable to the cytopathic effect of the enterotoxin. Cholera toxin (CT) (Sigma) at a concentration of $10 \mathrm{ng} / \mathrm{ml}$ was used as a positive control for enterotoxin activity and culture supernate of $E$. coli WF5 was used as the negative control.

\section{Cholera toxin-like factor assay}

The enzyme-linked immunosorbent assay (ELISA) method of Sack et al., ${ }^{18}$ modified by Miller et al. ${ }^{19}$ for the detection of CT, was used. Culture supernate $(100 \mu \mathrm{l})$ that had been heated at $56^{\circ} \mathrm{C}$ for $10 \mathrm{~min}$ was added to GM1 (monosialoganglioside) adsorbed to 96well Linbro microtitration plates (Flow Laboratories). After overnight incubation at room temperature, $100 \mu \mathrm{l}$ of goat anti-CT (University of Surrey) at a titre of 250 , and $100 \mu \mathrm{l}$ of peroxidase-labelled mouse antigoat immunoglobulins (Dako-Patt, Dako Ltd) were added sequentially to each well and incubated at $37^{\circ} \mathrm{C}$ for $1 \mathrm{~h}$ at each stage. $o$-Phenylene diamine dihydrochloride (Abbott Laboratories, USA) $(100 \mu \mathrm{l})$ was added as substrate and incubated at $37^{\circ} \mathrm{C}$ for $20 \mathrm{~min}$ after which the reaction was stopped by adding $20 \mu \mathrm{l}$ $8 \mathrm{~N} \mathrm{H}_{2} \mathrm{SO}_{4}$. The plates were read spectrophotometrically at $492 \mathrm{~nm}$ with a Dynatech MR600 Microelisa reader. A negative-positive cut-off value for each plate was calculated from the average values of negative control wells +2 SD. ${ }^{16} \mathrm{CT}$ (Sigma) at a concentration of $100 \mathrm{ng} / \mathrm{ml}$ was used as a positive control. Culture supernate of $E$. coli WF5 was used as a negative control.

\section{Results}

Table I shows the exotoxins produced by A. hydrophila strains isolated from different types of clinical specimen. Haemolysin production was demonstrated in $58-91 \%$ of strains and cytotoxin in 63 $96 \%$ of strains. In both cases the greatest proportion of toxin producers was amongst wound isolates ( 21 out of 23 for haemolysin, 22 of 23 for cytotoxin). Production of CTF was found in $16-33 \%$ of strains, the highest proportion of producers was amongst stool isolates (12 out of 38). Enterotoxin production was detected in fewer isolates, $10-22 \%$ only.

A comparison of the production of exotoxins by
Table I. Exotoxin production by $\boldsymbol{A}$. hydrophila isolates

\begin{tabular}{|c|c|c|c|c|c|}
\hline \multirow{2}{*}{ Source } & \multirow{2}{*}{$\begin{array}{c}\text { Total } \\
\text { number } \\
\text { tested }\end{array}$} & \multicolumn{4}{|c|}{ Number $(\%)$ of isolates that produced } \\
\hline & & haemolysin & cytotoxin & CTF & enterotoxin \\
\hline Stool & 38 & $22(58)$ & $24(63)$ & $12(32)$ & $5(13)$ \\
\hline Wound & 23 & $21(91)$ & $22(96)$ & $5(22)$ & $4(17)$ \\
\hline $\begin{array}{l}\text { Peritoneal } \\
\text { fluid }\end{array}$ & 10 & $8(80)$ & $8(80)$ & $3(30)$ & $1(10)$ \\
\hline Blood & 6 & $5(83)$ & $4(66)$ & $1(16)$ & $0(0)$ \\
\hline Others & 9 & $7(78)$ & $7(78)$ & $3(33)$ & $2(22)$ \\
\hline Total & 86 & 63 & 65 & 24 & 12 \\
\hline
\end{tabular}

isolates from enteric and non-enteric sources is shown in table II. Production of haemolysin and cytotoxin was commoner amongst the non-enteric isolates $(85 \%$ each). Of the enteric isolates, only $58 \%$ produced haemolysin and $63 \%$ cytotoxin. However, production of CTF was more pronounced amongst enteric isolates $(32 \%)$ than non-enteric isolates $(25 \%)$. Enterotoxin production was not prominent amongst these isolates although there was an even distribution between enteric (13\%) and non-enteric (14\%) isolates. None of the isolates from blood produced enterotoxin.

The exotoxin profiles of $A$. hydrophila isolates from clinical specimens are illustrated in table III. A wide range of exotoxin profiles was seen amongst enteric isolates, although eight isolates gave negative results in tests for all exotoxins studied. The non-enteric isolates were restricted to a few exotoxin profiles, although two of 48 isolates gave negative results in tests for all exotoxins studied. The commonest exotoxin profile in both enteric (12 of 38) and non-enteric (25 of 48) isolates was $\mathrm{Hly}^{+} / \mathrm{Cyt}^{+} / \mathrm{Ent}^{-} / \mathrm{CTF}^{-}$. The next most frequently occurring profile was $\mathrm{Hly}^{+} /$ $\mathrm{Cyt}^{+} / \mathrm{Ent}^{-} / \mathrm{CTF}^{+}$( 6 out of 38 for enteric, 8 out of 48 for non-enteric). None of the isolates exhibited $\mathrm{Hly}^{+} /$ $\mathrm{Cyt}^{-} / \mathrm{Ent}^{+} / \mathrm{CTF}^{+}, \quad \mathrm{HLY}^{+} / \mathrm{Cyt}^{-} / \mathrm{Ent}^{+} / \mathrm{CTF}^{-}$, or $\mathrm{Hly}^{-} / \mathrm{Cyt}^{+} / \mathrm{Ent}^{+} / \mathrm{CTF}^{-}$profiles. However, the $\mathrm{Hly}^{+}$ $/ \mathrm{Cyt}^{+} / \mathrm{Ent}^{+} / \mathrm{CTF}^{+}$profile, indicating the presence of all four exotoxins studied, was only produced by two of 48 non-enteric isolates. The $\mathrm{Hly}^{-} / \mathrm{Cyt}^{-} / \mathrm{Ent}^{+} /$ $\mathrm{CTF}^{-}$profile, indicative of production of enterotoxin only was found in one isolate from stool and another from peritoneal fluid.

Table IV shows the relationship between the

Table II. Comparison of exotoxin production between enteric and non-enteric isolates of $A$. hydrophila

\begin{tabular}{l|cc}
\hline \multirow{2}{*}{ Exotoxin } & \multicolumn{2}{|c}{ Number $(\%)$ of isolates that produced toxin } \\
\cline { 2 - 3 } & enteric $(\mathrm{n}=38)$ & non-enteric $(\mathrm{n}=48)$ \\
\hline Haemolysin & $22(58)$ & $41(85)$ \\
Cytotoxin & $24(63)$ & $41(85)$ \\
CTF & $12(32)$ & $12(25)$ \\
Enterotoxin & $5(13)$ & $7(14)$ \\
\hline
\end{tabular}


Table III. Exotoxin profiles of $\boldsymbol{A}$. hydrophila isolates from enteric and non-enteric sources

\begin{tabular}{|c|c|c|c|c|c|c|c|c|}
\hline & \multirow{3}{*}{\multicolumn{2}{|c|}{$\begin{array}{c}\text { Exotoxin } \\
\text { profile }\end{array}$}} & & \multicolumn{5}{|c|}{ Number of isolates with the given profile } \\
\hline & & & & \multirow{2}{*}{ Enteric } & \multicolumn{4}{|c|}{ Non-enteric } \\
\hline & & & & & Wound & Blood & $\begin{array}{l}\text { Peritoneal } \\
\text { fluid }\end{array}$ & Others* \\
\hline $\mathrm{Hly}^{+}$ & $\mathrm{Cyt}^{+}$ & Ent $^{+}$ & $\mathrm{CTF}^{+}$ & 0 & 1 & 0 & 0 & 1 \\
\hline $\mathrm{Hly}^{+}$ & $\mathrm{Cyt}^{+}$ & Ent $^{+}$ & $\mathrm{CTF}^{-}$ & 2 & 3 & 0 & 0 & 1 \\
\hline $\mathrm{Hly}^{+}$ & $\mathrm{Cyt}^{+}$ & Ent $^{-}$ & $\mathrm{CTF}^{-}$ & 12 & 14 & 2 & 6 & 3 \\
\hline $\mathrm{Hly}^{+}$ & $\mathrm{Cyt}^{-}$ & Ent $^{-}$ & $\mathrm{CTF}^{-}$ & 1 & 0 & 2 & 0 & 0 \\
\hline $\mathrm{Hly}^{-}$ & $\mathrm{Cyt}^{+}$ & Ent $^{+}$ & $\mathrm{CTF}^{+}$ & 1 & 0 & 0 & 0 & 0 \\
\hline $\mathrm{Hly}^{-}$ & $\mathrm{Cyt}^{-}$ & Ent $^{+}$ & $\mathrm{CTF}^{+}$ & 1 & 0 & 0 & 0 & 0 \\
\hline $\mathrm{Hly}^{-}$ & $\mathrm{Cyt}^{-}$ & $\mathrm{Ent}^{-}$ & $\mathrm{CTF}^{+}$ & 2 & 1 & 0 & 1 & 0 \\
\hline $\mathrm{Hly}^{-}$ & $\mathrm{Cyt}^{-}$ & Ent $^{-}$ & $\mathrm{CTF}^{-}$ & 8 & 0 & 0 & 0 & 2 \\
\hline $\mathrm{Hly}^{+}$ & $\mathrm{Cyt}^{-}$ & Ent $^{-}$ & $\mathrm{CTF}^{+}$ & 1 & 0 & 0 & 0 & 0 \\
\hline $\mathrm{Hly}^{+}$ & $\mathrm{Cyt}^{+}$ & Ent $^{-}$ & $\mathrm{CTF}^{+}$ & 6 & 3 & 1 & 2 & 2 \\
\hline $\mathrm{Hly}^{+}$ & $\mathrm{Cyt}^{-}$ & Ent $^{+}$ & $\mathrm{CTF}^{+}$ & 0 & 0 & 0 & 0 & 0 \\
\hline $\mathrm{Hly}^{+}$ & $\mathrm{Cyt}^{-}$ & Ent $^{+}$ & $\mathrm{CTF}^{-}$ & 0 & 0 & 0 & 0 & 0 \\
\hline $\mathrm{Hly}^{-}$ & $\mathrm{Cyt}^{+}$ & Ent $^{+}$ & $\mathrm{CTF}^{-}$ & 0 & 0 & 0 & 0 & 0 \\
\hline $\mathrm{Hly}^{-}$ & $\mathrm{Cyt}^{+}$ & $\mathrm{Ent}^{-}$ & $\mathrm{CTF}^{+}$ & 1 & 0 & 0 & 0 & 0 \\
\hline $\mathrm{Hly}^{-}$ & $\mathrm{Cyt}^{-}$ & $\mathrm{Ent}^{+}$ & $\mathrm{CTF}^{-}$ & 1 & 0 & 0 & 1 & 0 \\
\hline $\mathrm{Hly}^{-}$ & Cyt $^{+}$ & Ent $^{-}$ & $\mathrm{CTF}^{-}$ & 2 & 1 & 1 & 0 & 0 \\
\hline \multicolumn{2}{|c|}{ Total } & & & 38 & 23 & 6 & 10 & 9 \\
\hline
\end{tabular}

Hly, haemolysin; Cyt, cytotoxin; Ent, enterotoxin; CTF, cholera toxin-like factor.

* Urine, bile and tracheal secretions.

production of haemolysin and cytotoxin. With the exception of isolates from blood, a large proportion of non-enteric isolates (77-92\%) produced both haemolysin and cytotoxin. The production of either haemolysin or cytotoxin only, was found in $16 \%$ of enteric isolates and in $8 \%$ of the non-enteric isolates. However, amongst the non-enteric isolates, only one of 23 wound isolates and one of six blood-culture isolates produced cytotoxin but not haemolysin. Similarly, haemolysin production independent of cytotoxin production was found in two of six blood-culture isolates but not in any wound isolates. Thus, $50 \%$ of blood-culture isolates produced either exotoxin alone. Other non-enteric isolates did not express these exotoxins independently. The remaining $50 \%$ of blood-culture isolates produced both exotoxins in combination. However, as only small numbers of isolates from blood were studied,

Table IV. Relationship between production of haemolysin and cytotoxin in 86 strains of $A$. hydrophila

\begin{tabular}{|c|c|c|c|c|c|}
\hline \multirow{3}{*}{$\begin{array}{l}\text { Exotoxin } \\
\text { profile }\end{array}$} & \multicolumn{5}{|c|}{ Number (\%) of isolates with the given profile } \\
\hline & \multirow{2}{*}{ Enteric } & \multicolumn{4}{|c|}{ Non-enteric } \\
\hline & & Wound & $\begin{array}{l}\text { Peritoneal } \\
\text { fluid }\end{array}$ & Blood & Others \\
\hline $\mathrm{Hly}^{+} / \mathrm{Cyt}^{+}$ & $20(52)$ & $21(92)$ & $8(80)$ & $3(50)$ & $7(77)$ \\
\hline $\mathrm{Hly}^{-} / \mathrm{Cyt}^{+}$ & $4(11)$ & 1 (4) & 0 & $1(17)$ & \\
\hline $\mathrm{Hly}^{+} / \mathrm{Cyt}^{-}$ & $2(5)$ & 0 & 0 & $2(33)$ & 0 \\
\hline $\mathrm{Hly}^{-} / \mathrm{Cyt}^{-}$ & $12(31)$ & 1 (4) & $2(20)$ & 0 & $2(23)$ \\
\hline Total & 38 & 23 & 10 & 6 & 9 \\
\hline
\end{tabular}

See footnote to table III. these results should be interpreted with caution. Of enteric isolates, $31 \%$ gave negative results in tests for both exotoxins whereas a much smaller number of the non-enteric isolates gave negative results ( 5 of 48 , $10 \%$ ).

The relationship between the production of enterotoxin and CTF was examined (table V). Only a small proportion of isolates produced both exotoxins, two $(5 \%)$ of 38 for enteric isolates and two $(4 \%)$ of 48 for non-enteric isolates (including wound and urine isolates). Production of CTF alone occurred in $26 \%$ of enteric and $21 \%$ of non-enteric isolates. The production of enterotoxin alone occurred in $8 \%$ of enteric and $10 \%$ of non-enteric isolates. Therefore, generally, there was more often dissociation between production of CTF and enterotoxin (34\% and $31 \%$ respectively for enteric and non-enteric isolates).

Table V. Relationship between enterotoxin and CTF production in 86 strains of $A$. hydrophila

\begin{tabular}{|c|c|c|c|c|c|}
\hline \multirow{3}{*}{$\begin{array}{l}\text { Exotoxin } \\
\text { profile }\end{array}$} & \multicolumn{5}{|c|}{ Number $(\%)$ of isolates with the given profile } \\
\hline & \multirow{2}{*}{ Enteric } & \multicolumn{4}{|c|}{ Non-enteric } \\
\hline & & Wound & $\begin{array}{c}\text { Peritoneal } \\
\text { fluid }\end{array}$ & Blood & Others \\
\hline $\begin{array}{l}\text { Ent }^{+} / \mathrm{CTF}^{+} \\
\text {Ent }^{-} / \mathrm{CTF}^{+} \\
\text {Ent }^{+} / \mathrm{CTF}^{-} \\
\text {Ent }^{-} / \mathrm{CTF}^{-}\end{array}$ & $\begin{array}{r}2(5) \\
10(26) \\
3(8) \\
23(61)\end{array}$ & $\begin{array}{r}1(4) \\
4(16) \\
3(12) \\
15(68)\end{array}$ & $\begin{array}{l}0 \\
3(30) \\
1(10) \\
6(60)\end{array}$ & $\begin{array}{l}0 \\
1(17) \\
0 \\
5(83)\end{array}$ & $\begin{array}{l}1(11) \\
2(23) \\
1(11) \\
5(55)\end{array}$ \\
\hline Total & 38 & 23 & 10 & 6 & 9 \\
\hline
\end{tabular}

See footnote to table III. 


\section{Discussion}

Aeromonas spp. have been implicated as causative agents in wound infections, septicaemia and diarrhoea. The search for the mechanisms of pathogenicity has revealed that strains of Aeromonas produce a range of exotoxins. In this study, production of cytotoxin and haemolysin was prominent amongst isolates from various clinical sources and may be an inherent characteristic of $\boldsymbol{A}$. hydrophila irrespective of source of specimen, but haemolysin and cytotoxin activity were more common in extra-intestinal isolates and may signify the importance of these exotoxins in the pathogenesis of such infections. Asao et al. ${ }^{9}$ demonstrated that the haemolysin also had cytotoxic activity, suggesting that these two exotoxins may be the same protein. However, in our study, $5-33 \%$ of isolates produced haemolysin alone and cytotoxin alone was produced by $4-17 \%$ of strains (table IV). This indicates that the haemolysin and cytotoxin may be two different proteins and raises the possibility that the severity of infection, or ability to cause tissue damage, may be related to the presence of both exotoxins.

Despite the increasing body of information on $A$. hydrophila-associated gastroenteritis, the production of enterotoxin and the nature of the putative enterotoxin has been controversial. Turnbull et al. ${ }^{20}$ demonstrated fluid accumulation in the gut of infant mice suggesting the presence of an enterotoxin. Other workers have used Yl-adrenal ${ }^{10}$ and Vero cells ${ }^{21}$ in culture to establish the relationship between A. hydrophila enterotoxin and pathogenicity. In this study, enterotoxin was detected in tests with Vero cells in only a small number of isolates (table I). Furthermore, it was shown that amongst the isolates from faeces, CTF was found more often than enterotoxin, suggesting that CTF could be considered to be a marker of pathogenicity in A. hydrophila diarrhoea. However, if the genes responsible for CTF were similar to the LT genes of $E$. coli, which occur in single copy numbers and are present on transferrable plasmids, ${ }^{22}$ they could have been lost on subculture or storage. This may account for the lower number of CTF producers amongst faecal isolates examined in this study. However, in the pathogenesis of diarrhoea, additional factors such as colonisation factors and adhesins may need to be taken into account.

Chakraborty et al. ${ }^{23}$ have cloned the gene responsible for the production of enterotoxin; it is a chromosomal factor and distinct from the cytotoxin, haemolysin and known E. coli enterotoxins. The presence of a factor in the culture supernate of $A$. hydrophila that cross-reacts with anti-CT indicates the production of a CTF that may be responsible for diarrhoea. The ability to produce this factor may be due to the presence of a plasmid-borne toxin gene acquired from other gut bacteria. This hypothesis would require confirmation by DNA hybridisation studies and comparison with truly environmental isolates. Enterotoxin production was not found amongst blood-culture isolates, which suggests either the presence of factors in blood that may select for organisms that do not produce enterotoxin, or some unknown virulence factors that may be responsible for the invasive property of these strains.

It was evident from this study that non-enteric isolates displayed a more limited number of exotoxin profiles than enteric isolates. At least one type of exotoxin was elaborated by $80 \%$ of enteric and $96 \%$ of non-enteric isolates. The non-toxigenic isolates may have lost the toxin genes during culture or they may have been truly non-toxigenic. Haemolysin and cytotoxin production was found in isolates from both enteric and non-enteric sources whereas production of the enterotoxin and CTF were more prominent amongst enteric isolates, suggesting the possible importance of these exotoxins on their target sites.

In this investigation of the pathogenesis of aeromonas infections, tissue culture and serological assays were used to detect exotoxins. Further work is needed to elucidate, at the molecular level, the presence of the putative genes that code for protein exotoxins in isolates from various clinical and environmental sources.

This study was supported by a grant from Glaxo Malaysia Sendrian Berhad.

\section{References}

1. McCracken AW, Barkley R. Isolation of Aeromonas species from clinical sources. J Clin Pathol 1972; 25: 970-975.

2. Washington JA. Aeromonas hydrophila in clinical bacteriologic specimens. Ann Int Med 1972; 76: 611-614.

3. Gracey M, Burke V, Robinson J. Aeromonas-associated gastroenteritis. Lancet $1982 ; 2$ : 1304-1306.

4. Janda JM, Bottone EJ, Skinner CV, Calcaterra D. Phenotypic markers associated with gastrointestinal Aeromonas hydrophila isolates from symptomatic children. J Clin Microbiol $1983 ; 17: 588-591$

5. Pitarangsi C, Echeverria P, Whitmire, R et al. Enteropathogenicity of Aeromonas hydrophila and Plesiomonas shigelloides. Prevalence among individuals with and without diarrhea in Thailand. Infect Immun 1982; 35: 666-673.

6. Goodwin CS, Harper WES, Steward JK, Gracey M, Burke V, Robinson J. Enterotoxigenic Aeromonas hydrophila and diarrhoea in adults. Med J Aust 1983; 1: 25-26.

7. Donta ST, Haddow AD. Cytotoxic activity of Aeromonas hydrophila. Infect Immun 1978; 21 : 989-993.

8. Wretlind B, Mölby R, Wadström T. Separation of two hemolysins from Aeromonas hydrophila by isoelectric focusing. Infect Immun 1971; 4: 503-505.

9. Asao T, Kinoshita Y, Kozaki S, Uemura T, Sakaguchi G. Purification and some properties of Aeromonas hydrophila hemolysin. Infect Immun 1984; 46: 122-127.

10. Ljungh A, Popoff M, Wadström T. Aeromonas hydrophila in acute diarrheal disease. Detection of enterotoxin and biotyping of strains. J Clin Microbiol 1977; 6: 96-100.

11. Campbell JD, Houston CW. Effect of cultural conditions on the presence of a cholera toxin cross-reactive factor in culture filtrates of Aeromonas hydrophila. Curr Microbiol $1985 ; 12$ : 101-106.

12. Cumberbatch N, Gurwith MJ, Langston C, Sack RB, Brunton JL. Cytotoxic enterotoxin produced by Aeromonas hydrophila: relationship of toxigenic isolates to diarrheal disease. Infect Immun 1979; 23: 829-837.

13. James $\mathbf{C}$, Dibley $\mathbf{M}$, Burke $\mathbf{V}$, Robinson $\mathbf{J}$, Gracey $\mathbf{M}$. Immunological cross-reactivity of enterotoxins of Aero- 
monas hydrophila and cholera toxin. Clin Exp Immunol $1982 ; 47: 34-42$.

14. Speirs JI, Stavric S, Konowalchuk J. Assay of Escherichia coli heat-labile enterotoxin with vero cells. Infect Immun 1977; 16: 617-622.

15. Giugliano LG, Mann GF, Drasar BS. Response of mammalian cell lines to the toxins of Escherichia coli. J Med Microbiol 1982; 15: 531-539.

16. Vadivelu J, Dunn DT, Feachem RG et al. Comparison of five assays for the heat-labile enterotoxin of Escherichia coli. $J$ Med Microbiol 1987; 23: 221-226.

17. Wadström T, Ljungh $\AA$, Wretlind B. Enterotoxin, haemolysin and cytotoxic protein in Aeromonas hydrophila from human infections. Acta Pathol Microbiol Scand 1976; Sect B 84: $112-114$.

18. Sack DA, Huda S, Neogi PKB, Daniel RR, Spira WM. Microtiter ganglioside enzyme-linked immunosorbent assay for vibrio and Escherichia coli heat-labile enterotoxins and antitoxins. J Clin Microbiol 1980; 11 : 35-40.
19. Miller CJ, Drasar BS, Feachem RG, Hayes RJ. The impact of physico-chemical stress on the toxigenicity of Vibrio cholerae. J Hyg 1986; 96: 49-57.

20. Turnbull PCB, Lee JV, Miliotis MD et al. Enterotoxin production in relation to taxonomic grouping and source of isolation of Aeromonas species. J Clin Microbiol 1984; 19: $175-180$.

21. Millership SE, Barer MR, Tabaqchali S. Toxin production of Aeromonas spp. from different sources. $J$ Med Microbiol 1986; $22:$ 311-314.

22. Black RE, Merson MH, Rahman ASMM et al. A two-year study of bacterial, viral, and parasitic agents associated with diarrhea in rural Bangladesh. J Infect Dis 1980; 142: 660-664.

23. Chakraborty T, Montenegro MA, Sanyal SC, Helmuth R, Bulling E, Timmis KN. Cloning of enterotoxin gene from Aeromonas hydrophila provides conclusive evidence of production of a cytotonic enterotoxin. Infect Immun 1984; 46: 435-441. 
